\title{
PENGARUH CORPORATE SOCIAL RESPONSIBILITY TERHADAP KINERJA KEUANGAN PERUSAHAAN DAN EARNING MANAGEMENT SEBAGAI VARIABEL MODERASI
}

\author{
Jessica Ang \\ Management Department, Universitas Surabaya, Indonesia \\ janggelina@gmail.com \\ Werner R. Murhadi \\ Management Department, Universitas Surabaya, Indonesia \\ Werner@staff.ubaya.ac.id \\ Endang Ernawati \\ Management Department, Universitas Surabaya, Indonesia \\ endangernawati@yahoo.com
}

\begin{abstract}
This study aims to analyze the effect of corporate social responsibility on a company's financial performance with earning management as a moderating variable. The variables used in this study are corporate social responsibility, firm age, firm size, leverage, and earning management as moderation variables. This research uses a quantitative approach using multiple linear regression analysis. The target population in this study are all non-financial sector companies listed on the Indonesia Stock Exchange (IDX) in 2014-2018, which amounted to 875 observations. The results showed that corporate social responsibility variable has no significant influence on financial performance. The analysis with moderating variables show that earning management can strengthen the relationship between corporate social responsibility and financial performance.
\end{abstract}

Keywords: corporate social responsibility, financial performance, earning management

\section{LATAR BELAKANG}

Pada era globalisasi saat ini, perusahaan harus berusaha untuk terus berinovasi dan meningkatkan strategi agar mampu bersaing. Inovasi dilakukan demi menjaga keberlangsungan hidup perusahaan dan juga sebagai upaya perusahaan dalam meningkatkan kinerjanya. Salah satu strategi dalam meningkatkan kinerja perusahaan adalah dengan melakukan kegiatan yang memberikan manfaat atau dampak positif tidak hanya untuk perusahaan, tetapi juga masyarakat sebagai bagian dari stakeholder. Kegiatan tersebut adalah tanggung jawab sosial atau corporate social responsibility (CSR). Penerapan CSR dinilai sangat penting untuk menjadi bagian dari strategi perusahaan. Nyeadi et al. (2018) mengungkapkan bahwa alasan 
perusahaan melibatkan diri dalam kegiatan CSR adalah untuk membangun citra perusahaan, mendapatkan legitimasi, beradaptasi dengan peluang, mendapatkan perlindungan terhadap tantangan dan ancaman eksternal serta dapat memaksimalkan laba perusahaan. Penerapan CSR di Indonesia diatur dalam Undang-Undang Nomor 40 tahun 2007 tentang Perseroan Terbatas serta Peraturan Pemerintah Nomor 47 tahun 2012 pasal 47 terkait dengan tanggung jawab sosial dan lingkungan perseroan terbatas.

Pengungkapan CSR muncul seiring dengan earning management yang dilakukan oleh manajer. Penggungkapan CSR digunakan sebagai strategi pertahanan diri untuk mengantisipasi ketidakpuasan stakeholder terhadap kinerja perusahaan yang kurang memuaskan. Strategi tersebut digunakan sebagai upaya dalam mempertahankan reputasi perusahaan dan secara pribadi dapat melindungi karir manajer (Fombrun et al. 2000). Prior et al. (2008) mengatakan bahwa strategi untuk menjaga hubungan dan mendapatkan dukungan dari stakeholder adalah dengan memanipulasi pendapatan menggunakan kegiatan CSR. Prior et al. (2008) juga menemukan bahwa dalam jangka panjang pengaruh antara earning management dan CSR akan berdampak pada kinerja keuangan perusahaan.

Hubungan yang kuat dengan beberapa stakeholder, klien, dan masyarakat merupakan bagian dari ruang lingkup CSR. Beberapa aspek penting CSR telah menjadi objek penelitian, seperti konseptualisasi, pengungkapan, dan kemungkinan adanya hubungan antara CSR dan kinerja keuangan perusahaan (Crisostomo et al., 2011). Dari survei terbaru, terdapat 100 perusahaan besar dari 45 negara yang menunjukkan bahwa sekitar $56 \%$ perusahaan mengungkapkan informasi terkait aktivitas tanggung jawab sosial (CSR) di laporan keuangan mereka, sementara pada tahun 2011 pengungkapannya sekitar $20 \%$ dan tahun 2008 hanya sekitar $8 \%$ saja (Kabir dan Thai, 2017).

Kegiatan CSR dinilai dapat memberikan pengaruh terhadap kinerja keuangan perusahaan. Penelitian yang dilakukan oleh Sial et al. (2018), Nyeadi et al. (2018), dan Khabir and Thai (2017) yang mengatakan bahwa CSR memiliki pengaruh signifikan positif terhadap kinerja keuangan perusahaan yang diukur menggunakan Tobin's Q dan ROA. Teori stakeholder mengatakan bahwa ketika sebuah perusahaan memperhatikan semua kebutuhan stakeholder, maka akan meningkatkan citra dan reputasi perusahaan sehingga dapat menciptakan nilai dan peningkatan pada kinerja keuangan perusahaan (Nyeadi et al., 2018). Namun temuan di atas bertentangan dengan teori biaya agensi yang mengatakan bahwa ketika perusahaan menggunakan sumber dayanya untuk kegiatan CSR, maka perusahaan sedang mengalihkan sumber dananya dari penggunaan yang produktif sehingga memberikan efek negatif pada kekayaan dan keuntungan pemegang saham (Nyeadi et al., 2018). Selain bertentangan dengan teori biaya agensi penelitian tersebut juga bertentangan dengan penelitian Crisostomo et al. (2011) yang mengatakan bahwa CSR dan kinerja keuangan perusahaan memiliki hubungan yang negatif tidak signifikan jika diukur menggunakan ROA. 
Selain CSR, terdapat faktor lain yang dapat mempengaruhi kinerja keuangan yaitu firm age, firm size, dan leverage. Sial et al. (2018) dan Nyeadi et al. (2018) dalam penelitiannya menemukan bahwa firm age memiliki pengaruh signifikan positif terhadap kinerja keuangan perusahaan yang diukur menggunakan Tobin's Q. Hal ini mengindikasikan bahwa semakin lama umur perusahaan maka kinerja keuangan dari perusahaan tersebut juga akan semakin baik. Hasil penelitian ini konsisten dengan penelitian sebelumnya (Sial et al., 2018). Khabir dan Thai (2017) meneliti bahwa firm age berpengaruh tidak signifikan terhadap kinerja keuangan (Tobin's Q). Penggukuran menggunakan ROA memberikan hasil yang berbeda untuk firm age. Nyeadi et al. (2018) dalam penelitiannya menemukan bahwa firm age memberikan hasil negatif signifikan terhadap kinerja keuangan perusahaan sedangkan Kabir et al. (2017) menemukan bahwa firm age memberikan hasil positif signifikan terhadap kinerja keuangan perusahaan.

Nyeadi et al. (2018) menemukan bahwa firm size berpengaruh signifikan negatif terhadap kinerja keuangan (Tobin's Q dan ROA). Artinya jika perusahaan memiliki skala yang besar maka kemungkinan kinerja perusahaan akan menurun, sedangkan Kabir and Thai (2017) menemukan bahwa firm size berpengaruh signifikan positif terhadap kinerja keuangan (Tobin's Q dan ROA) beda halnya dengan Sial et al. (2018) yang meneliti bahwa firm size berpengaruh tidak signifikan terhadap kinerja keuangan perusahaan yang diukur menggunakan Tobin's Q dan Crisostomo et al. (2011) yang meneliti bahwa firm size berpengaruh tidak signifikan terhadap kinerja keuangan perusahaan yang diukur menggunakan ROA.

Sial et al. (2018) dan Kabir and Thai (2017) mengatakan bahwa leverage berpengaruh secara negatif signifikan terhadap kinerja keuangan (Tobin's Q). Hal ini mengindikasikan bahwa semakin besar hutang perusahaan maka kinerja keuangannya akan semakin menurun. Beda halnya dengan Nyeadi et al. (2018) mengatakan bahwa leverage berpengaruh tidak signifikan terhadap kinerja keuangan perusahaan (Tobin's Q). Nyeadi et al. (2018), Kabir and Thai (2017), dan Crisostomo et al. (2011) yang mengatakan bahwa leverage berpengaruh secara signifikan negatif terhadap kinerja keuangan perusahaan jika diukur menggunakan ROA.

\section{METODE PENELITIAN}

Penelitian ini termasuk jenis basic research dikarenakan tujuan dari penelitian ini adalah untuk mengembangkan penelitian yang telah dilakukan sebelumnya. Berdasarkan tujuan, penelitian ini termasuk jenis penelitian causal research karena penelitian dilakukan untuk menguji pengaruh variabel independen yaitu corporate social responsibility terhadap variabel dependen yaitu kinerja keuangan pada perusahaan yang terdaftar di Bursa Efek Indonesia periode 2014-2018. Berdasarkan pendekatan, penelitian ini menggunakan pendekatan kuantitatif karena penelitian ini melibatkan data-data yang bersifat kuantitatif dalam proses pengolahan data menjadi informasi. Penelitian ini menggunakan 2 variabel dependen yaitu Tobin's Q dan return on asset (ROA), 1 variabel independen yaitu corporate social responsibility 
(CSR), 1 variabel moderasi yaitu earning management dan 3 variabel kontrol yaitu firm age, firm size, dan leverage.

Penelitian ini menggunakan seluruh perusahaan yang terdaftar di Bursa Efek Indonesia periode 2014-2018 sebagai populasi. Karakteristik dari populasi tersebut yaitu: (1) badan usaha sektor non-keuangan yang terdaftar di Bursa Efek Indonesia secara berturut-turut selama periode 2014-2018, (2) memiliki dan menerbitkan laporan keuangan dan tahunan selama periode 2014-2018, (3) tersedia data untuk seluruh variabel yang dibutuhkan dalam laporan keuangan, (4) tidak melakukan IPO dalam waktu dekat atau selama waktu penelitian.

Jenis data yang digunakan dalam penelitian ini adalah data sekunder, karena data diperoleh dari laporan keuangan seluruh badan usaha sektor non keuangan selama periode 2014-2018. Data yang digunakan diperoleh melalui laporan keuangan dan laporan tahunan seluruh badan usaha sektor non-keuangan yang terdaftar di Bursa Efek Indonesia periode 2014-2018 melalui website www.idx.com dan www.idnfinancials.com.

Penelitian ini menggunakan analisis regresi linier berganda dengan dua model persamaan untuk menguji hipotesis pengaruh variabel independen terhadap variabel dependen dan pengaruh variabel moderasi (earning management) terhadap CSR dan kinerja keuangan perusahaan. Selain itu, penelitian ini menggunakan Moderating Regression Analysis (MRA) yang merupakan aplikasi khusus regresi linear berganda yang dalam persamaan regresinya mengandung unsur interaksi (perkalian dua atau lebih variabel independen). MRA dipilih dalam penelitian ini karena dapat menjelaskan pengaruh variabel dependen dengan variabel independen serta variabel moderasi dalam memperkuat maupun memperlemah hubungan variabel dan untuk mengetahui kemampuan variabel manajemen laba dalam memoderasi pengaruh pengungkapan CSR pada kinerja keuangan.

FPit $=\beta 0+\beta 1$ CSRit $+\beta 2$ AGEit $+\beta 3$ lnSIZEit $+\beta 4$ LEVit $+\varepsilon$ it

FPit $=\alpha+\beta 1$ CSRit $+\beta 2$ DAit $+\beta 3$ CSRitDAit $+\beta 4$ AGEit $+\beta 5$ lnSIZEit $+\beta 6$

LEVit + cit

Keterangan:

FP $\quad=$ kinerja keuangan perusahaan (Tobin's Q dan ROA)

CSR = corporate Social Responsibility

DA = discretionary accruals

CSR $x$ DA = interaksi antara CSR dan discretionary accruals

AGE = umur Perusahaan

SIZE $=$ ukuran Perusahaan

LEV = leverage

$\beta 1, \beta 2, \beta 3=$ koefisien regresi

$\varepsilon \quad=$ error 


\section{HASIL DAN DISKUSI}

Penelitian ini menggunakan perusahaan sektor non-keuangan yang terdaftar di BEI periode 2014-2018. Terdapat total 653 perusahaan yang terdaftar di BEI tahun 2018, namun perushaan yang memenuhi kriteria dalam penelitian ini hanya 175 perusahaan.

Tabel 1.

Statistik Deskriptif

\begin{tabular}{lcrrrr}
\hline & $\mathrm{N}$ & \multicolumn{1}{c}{ Minimum } & \multicolumn{1}{c}{ Maximum } & \multicolumn{1}{c}{ Mean } & Std. Deviation \\
\hline TQ & 875 & -0.00880 & 194.44720 & 1.48470 & 7.21254 \\
ROA & 875 & -10.88936 & 0.92100 & 0.02598 & 0.38838 \\
CSR & 875 & -0.00110 & 0.31440 & 0.00366 & 0.01686 \\
DA & 875 & -1.83707 & 1.71414 & -0.03634 & 0.17519 \\
AGE & 875 & 6 & 147 & 36 & 18 \\
SIZE & 875 & 25.21557 & 32.95985 & 28.94326 & 1.59484 \\
LEV & 875 & 0.03873 & 19.51133 & 0.55564 & 1.04437 \\
Valid N (listwise) & 875 & & & & \\
\hline Sumber: Pengolahan
\end{tabular}

(Sumber: Pengolahan data dengan SPSS 24.0)

Kinerja keuangan perusahaan merupakan variabel dependen yang dapat diproksikan melalui Tobin's Q dan ROA. Pada variabel Tobin's Q (TQ), nilai minimum diperoleh dari perusahaan ENRG 2017 sedangkan nilai maximum diperoleh dari perusahaan TRIO 2017 dan pada variabel return on asset (ROA), nilai minimum dan maximum masing-masing diperoleh dari perusahaan TRIO 2015 dan MERK 2018. Variabel independen yang digunakan adalah corporate social responsibility (CSR) dengan nilai minimun diperoleh dari perusahaan SPMA 2016 sedangkan nilai maximum diperoleh dari perusahaan BUMI 2017. Variabel moderasi yang digunakan yaitu earning management yang diproksikan menggunakan discretionary accrual (DA) dengan nilai minimum diperoleh dari perusahaan BSSR 2017 sedangkan nilai maximum diperoleh dari perusahaan BUMI 2014. Selain itu, terdapat 3 variabel kontrol dengan penjelasan sebagai berikut: (1) age, nilai minimum diperoleh dari perusahaan TOWR 2014 sedangkan nilai maximum diperoleh dari perusahaan KAEF 2018; (2) size, nilai minimum diperoleh dari perusahaan BIMA 2017 sedangkan nilai maximum diperoleh dari perusahaan TLKM 2018; (3) leverage, nilai minimum diperoleh dari perusahaan IIKP 2015 sedangkan nilai maximum diperoleh dari perusahaan TRIO 2018. Pada tabel 2 dan tabel 3 akan dijelaskan mengenai pengaruh antar variabel satu dengan variabel lainnya. 
Tabel 2.

Hasil Uji Regresi Kinerja Keuangan (Tobin's Q)

\begin{tabular}{lcccccc}
\hline \multirow{2}{*}{ Variabel } & \multicolumn{3}{c}{ Model 1 } & & \multicolumn{3}{c}{ Model 2 } \\
(Constant) & Beta & $\mathrm{t}$ & $\mathrm{Sig}$ & $\mathrm{Beta}$ & $\mathrm{t}$ & Sig \\
\cline { 2 - 7 } CSR & 5.786 & 1.538 & .124 & & & \\
DA & -8.836 & -.723 & .470 & -11.974 & -.784 & .433 \\
CSR x DA & & & & -.920 & -.691 & .489 \\
Firm Age & -.002 & -.213 & .831 & -.003 & -.229 & .819 \\
Firm Size & -.216 & -1.648 & $.100^{*}$ & -.229 & -1.731 & $.084^{*}$ \\
Leverage & 3.707 & 18.788 & $.000^{* * *}$ & 3.718 & 18.770 & $.000^{* * *}$ \\
\hline
\end{tabular}

(Sumber: Pengolahan data dengan SPSS 24.0)

$\begin{array}{lll}\text { Keterangan } & : * & : \text { signifikan pada } 10 \% \\ & * * & : \text { signifikan pada } 5 \% \\ & * * * & : \text { Signifikan pada } 1 \%\end{array}$

Tabel 3.

Hasil Uji Regresi Kinerja Keuangan (ROA)

\begin{tabular}{lcccccc}
\hline \multirow{2}{*}{ Variabel } & \multicolumn{3}{c}{ Model 1 } & \multicolumn{3}{c}{ Model 2 } \\
CSR & Beta & $\mathrm{t}$ & $\mathrm{Sig}$ & Beta & $\mathrm{t}$ & Sig \\
\cline { 2 - 7 } DA & -.231 & -.317 & .751 & -.920 & -1.020 & .308 \\
CSR x DA & & & & -.277 & -3.527 & $.000^{* * *}$ \\
Firm Age & .001 & 1.137 & .256 & .001 & 1.064 & $.025^{* *}$ \\
Firm Size & .009 & 1.102 & .271 & .005 & .581 & .288 \\
Leverage & -.135 & -11.539 & $.000^{* * *}$ & -.132 & -11.296 & $.000^{* * *}$ \\
\hline
\end{tabular}

(Sumber: Pengolahan data dengan SPSS 24.0)

Keterangan $\quad: * \quad$ : signifikan pada $10 \%$

** : signifikan pada $5 \%$

*** : Signifikan pada $1 \%$

Pada tabel di atas, menunjukan bahwa CSR tidak memiliki pengaruh terhadap Tobin's Q baik pada model 1 atapun model 2. Hasil ini didukung oleh penelitian Margaretha dan Witedjo (2014) dan Atmadja (2019), namun tidak mendukung hipotesis awal dan penelitian Sial et al. (2018), Nyeadi et al. (2018), dan Kabir and Thai (2017). Margaretha dan Witedjo (2014) menjelaskan bahwa investor di Negara berkembang kurang peduli dengan laporan tanggung jawab sosial perusahaan sehingga CSR yang dilakukan perusahaan di Indonesia masih belum dapat mempengaruhi kinerja perusahaan. Dewi dan Monalisa (2016) juga menunjukkan bahwa tidak adanya standar pelaporan dari CSR sehingga terdapat perbedaan jumlah 
laporan kegiatan CSR antara satu perusahaan dengan perusahaan lain dapat membuat investor enggan untuk melihat laporan pengungkapan kegiatan CSR serta tidak memasukkan laporan tersebut dalam menentukan keputusan investasi. Selain itu, hasil penelitian menunjukkan bahwa CSR tidak memiliki pengaruh terhadap ROA. Hasil ini sesuai dengan penelitian Crisostomo et al. (2011) dan didukung oleh Fauzi et al. (2017) akan tetapi bertentangan dengan hipotesis awal dan penelitian Nyeadi et al. (2018) dan Kabir and Thai (2017). Fauzi et al. (2017) menjelaskan bahwa hal ini disebabkan karena kegiatan CSR di Indonesia merupakan kegiatan wajib yang harus dilakukan perusahaan sehingga kebanyakan perusahaan menghindari untuk memberikan informasi yang relevan serta tidak memikirkan dampaknya terhadap masyarakat. Hal tersebut membuat kinerja keuangan perusahaan tidak terpengaruh.

Pada tabel 2 dapat dilihat bahwa koefisien variabel earning management adalah 9,157 dengan tingkat signifikansi sebesar 0,599 yang menunjukkan jika variabel earning management tidak memperkuat maupun mempeerlemah hubungan antara CSR dan Tobin's Q. Hasil ini didukung oleh penelitian Wijaya dan Sherly (2017) dan Atmadja (2019), namun bertentangan dengan hipotesis awal dan penelitian Sial et al. (2018). Menurut Wijaya dan Sherly (2017) hal ini dikarenakan pengungkapan CSR bersifat mandatory disclosure yang berarti perusahaan wajib untuk mengungkapkan kegiatan CSR, sehingga perusahaan tidak terlalu peduli terhadap dampak yang akan diterima masyarakat. Selain itu, investor juga tidak melihat earning management sebagai hal penting yang harus dipertimbangkan dalam melakukan investasi tetapi lebih memilih investasi yang aman dengan memperhitungkan return yang akan diterima, sehingga earning management tidak mempengaruhi hubungan antara CSR dengan kinerja perusahaan (Sabatini dan Sudana, 2019). Selain itu, pada tabel 3 dapat dilihat bahwa koefisien variabel earning management adalah 2,310 dengan tingkat signifikansi sebesar 0,025 yang menunjukkan jika variabel earning management dapat memperkuat efek CSR terhadap kinerja keuangan (ROA). Hasil ini didukung oleh penelitian Mahrani dan Soewarno (2018), namun bertentangan dengan hipotesis awal dan penelitian Sial et al. (2018). Mahrani dan Soewarno (2018) mengatakan bahwa pengungkapan kegiatan CSR dapat membantu perusahaan mendapatkan dukungan dari lingkungan masyarakat dan dengan adanya praktik earning management akan membuat laporan keuangan perusahaan semakin menarik sehingga membuat kinerja keuangan meningkat.

Pada tabel 2, dapat dilihat bahwa koefisien variabel firm age pada kedua model adalah -0,002 dan -0,003 dengan tingkat signifikansi masing-masing sebesar 0,831 dan 0,819 yang menunjukkan jika variabel firm age tidak berpengaruh terhadap Tobin's Q. Hasil ini sesuai dengan penelitian Kabir and Thai (2017) namun bertentangan dengan hipotesis awal dan penelitian Sial et al. (2018) dan Nyeadi et al. (2018). Hal ini dikarenakan lamanya umur perusahaan tidak selalu mencerminkan adanya peningkatan pada market value. Perusahaan yang sudah lama berdiri seperti Unilever dan juga perusahaan yang baru berdiri seperti perusahaan startup Unicorn memiliki market value yang sama besar, sehingga kinerja suatu perusahaan tidak 
dapat dinilai dari umur saja. Selain itu, pada tabel 3 dapat dilihat bahwa koefisien variabel firm age pada kedua model adalah 0,001 dan 0,001 dengan tingkat signifikansi masing-masing sebesar 0,256 dan 0,288 yang menunjukkan jika variabel firm age tidak memiliki pengaruh terhadap ROA. Hasil penelitian ini didukung oleh penelitian Rashid (2017), namun bertentangan dengan hipotesis awal dan penelitian Nyeadi et al. (2018), Kabir and Thai (2017), dan Crisostomo et al. (2011). Lamanya umur perusahaan tidak membuat perusahaan lebih profit daripada perusahaan yang baru berdiri, sebab pada saat tertentu pendapatan perusahaan yang telah lama berdiri seperti Kimia Farma akan mengalami penurunan yang disebabkan oleh munculnya perusahaan baru seperti perusahaan startup Unicorn. Selain itu, perusahaan yang baru berdiri memiliki kemampuan untuk menghasilkan output yang lebih baik dibandingkan dengan perusahaan yang lama (Rashid, 2017).

Pada tabel 2, dapat dilihat bahwa koefisien variabel firm size pada kedua model adalah $-0,216$ dan $-0,229$ dengan tingkat signifikansi masing-masing sebesar 0,1 dan 0,084 yang menunjukkan jika variabel firm size memiliki hubungan yang negatif signifikan dengan Tobin's Q. Hasil ini didukung oleh penelitian Mathew (2017) dan Lin and $\mathrm{Fu}$ (2017), namun bertentangan dengan hipotesis awal dan penelitian Sial et al. (2018) dan Nyeadi et al. (2018). Xu dan Wang (1999); Sun dan Tong (2003) dalam Lin dan Fu (2017) menemukan bahwa semakin besar ukuran perusahaan maka perusahaan akan mendapat banyak masalah birokrasi, memiliki biaya agensi yang lebih tinggi, dan kurangnya fleksibilitas dalam merespon perubahan kondisi pasar sehingga kinerja keuangan perusahaan akan menurun. Selain itu, pada tabel 3, dapat dilihat bahwa koefisien variabel firm size pada kedua model adalah 0,009 dan 0,005 dengan tingkat signifikansi masing-masing sebesar 0,271 dan 0,561 yang menunjukkan jika variabel firm size memiliki hubungan yang positif tidak signifikan dengan ROA. Hasil penelitian ini bertentangan dengan hipotesis awal namun didukung oleh penelitian Kumar dan Kaur (2016). Kumar dan Kaur (2016) yang mengatakan bahwa profitabilitas independen (berdiri sendiri) dari ukuran perusahaan. Ukuran perusahaan bukanlah sebuah jaminan bahwa perusahaan besar memiliki kinerja yang bagus begitu pula sebaliknya.

Pada tabel 2 dapat dilihat bahwa koefisien variabel leverage pada kedua model adalah 3,707 dan 3,718 dengan tingkat signifikansi masing-masing sebesar 0,000 dan 0,000 yang menunjukkan jika variabel leverage memiliki hubungan yang positif signifikan dengan Tobin's Q. Hasil ini didukung oleh penelitian Rodrigs et al. (2017) yang mengatakan tingginya utang dapat meningkatkan kontrol eksternal, ketatnya kontrol eksternal membuat perusahaan dengan leverage yang tinggi akan cenderung berinvestasi pada proyek-proyek yang lebih menguntungkan dan memiliki kinerja yang lebih baik serta dapat meningkatkan market value perusahaan dibanding perusahaan dengan leverage yang rendah. Selain itu, pada tabel 3 dapat dilihat bahwa koefisien variabel leverage pada kedua model adalah $-0,135$ dan $-0,132$ dengan tingkat signifikansi masing-masing sebesar 0,000 dan 0,000 yang menunjukkan jika variabel leverage memiliki hubungan yang negatif signifikan dengan ROA. Hasil ini sesuai dengan penemuan Nyeadi et al. (2018), Kabir and Thai (2017), dan Criostomo 
et al. (2011) dan didukung oleh Isbanah (2015) yang mengatakan bahwa perusahaan akan menjadi kurang baik apabila menggunakan utang terlalu besar dikarenakan adanya risiko yang lebih besar dibandingkan dengan peningkatan keuntungan perusahaan.

\section{KONKLUSI}

Dari hasil analisis logistic regression dengan menggunakan software SPSS yang telah diolah dan dibahas pada bab sebelumnya, terdapat lima variabel yang masuk dalam model kinerja keuangan, yaitu corporate social responsibility, discretionary accrual, firm age, firm size, dan leverage. Pada model 1a dan 1b, terdapat satu variabel yang menunjukkan hasil positif (leverage), satu variabel yang menunjukkan hasil negatif (size), dan tiga variabel menunjukkan hasil yang tidak signifikan (CSR, age, dan CSRxDA). Pada model $2 \mathrm{a}$ dan $2 \mathrm{~b}$, terdapat satu variabel yang menunjukkan hasil positif (CSRxDA), satu variabel yang menunjukkan hasil negatif (leverage), dan tiga variabel menunjukkan hasil yang tidak signifikan (CSR, age, dan size).

Berdasarkan hasil uji $\mathrm{F}$ pada model $1 \mathrm{a}$ dan $1 \mathrm{~b}$, didapatkan masing-masing $\mathrm{F}$ hitung sebesar 90,869 dan 34,990 dengan tingkat signifikansi sebesar 0,000<0,05. Hal ini berarti bahwa variabel independen (CSR, age, size, dan leverage) secara bersama-sama mempengaruhi variabel dependen (Tobin's Q dan ROA). Pada model $2 \mathrm{a}$ dan $2 \mathrm{~b}$, didapatkan masing-masing $\mathrm{F}$ hitung sebesar 60,569 dan 25,829 dengan tingkat signifikansi sebesar $0,000<0,05$. Hal ini berarti bahwa variabel independen (CSR, discretionary accrual, CSRxDA, age, size, leverage) secara bersama-sama mempengaruhi variabel dependen (Tobin's Q dan ROA).

Terdapat beberapa keterbatasan dalam penelitian ini, yaitu pada metode dalam mengukur CSR. Diharapkan untuk penelitian berikutnya dapat menggunakan metode lain dalam mengukur CSR, menambah jumlah variabel lain, periode penelitian dan objek negara berkembang lainnya agar mendapatkan hasil yang lebih valid.

\section{REFERENCES}

Atmadja. (2019). Pengaruh Pengungkapan Corporate Social Responsibility terhadap Kinerja Keuangan: Studi Empiris pada Perusahaan yang Terdaftar di Indeks SriKehati Bursa Efek Indonesia. E-Jurnal Ekonomi Bisnis dan Akuntansi, 6(1), 127134. DOI:10.19184/ejeba.v6i2.11156.

Crisostomo et al. 2011. Corporate Social Responsibility, Firm Value and Financial Performance in Brazil. Social Responsibility Journal, 7, 295-309. DOI:10.1108/17471111111141549

Dewi, k. \& Monalisa. (2016). Effect of Corporate Social Responsibility Disclosure on Financial Performance with Audit Quality as a Moderating Variable. Binus Business Review, 7(2), 149-155.

Fauzi et al. 2007. Institutional Ownership and Corporate Social Performance: Empirical Evidence from Indonesian Companies. Issues in Social and Environmental Accounting. 1(2), 334-347. Available from http://ssrn.com/abstract $=1489310$ 
Fombrun et al. 2000. Opportunity Platforms and Safety Nets: Corporate Citizenship and Reputational Risk. Business and Society Review, 105(7), 85-106.

Isbanah Y. 2015. Pengaruh Esop, Leverage, dan Ukuran Perusahaan terhadap Kinerja Keuangan Perusahaan di Bursa Efek Indonesia. Jurnal Riset Ekonomi dan Manajemen, 15(1), 28-41. DOI: 10.17970/jrem.15.150103

Kabir R, HM Thai. 2017. Does Corporate Governance Shape The Relationship between Corporate Social Responsibility and Financial Performance?. Pacific Accounting Review. 29, 227-258. DOI:10.1008/PAR-10-2016-0091

Kumar N, Kaur K. 2016. Firm Size and Profitability in Indian Automobile Industry: An Analysis. Pacific Business Review International. 8(7): 69-78.

Lin YR, XM Fu. 2017. Does Institutional Ownership Influence Firm Performance? Evidence from China. International Review of Economics and Finance. 49, 17 57.

Mahrani M, Soewarno N. 2018. The Effect of Good Corporate Governance Mechanism and Corporate Social Responsibility on Financial Performance with Earning Management as Mediating Variabel. Asian Journal of Accounting Research. 3(1), 41-60. DOI:10.1108/AJAR-06-2018-0008

Margaretha F, Chandra GW. 2018. CSR, Nilai Perusahaan dan Kinerja Keuangan Perusahaan pada Industri Pertambangan dan Manufaktur di Indonesia. Media Riset Akuntansi, Auditing dan Informasi. 14(1). DOI:10.25105/mraai.v14i1.1754

Matthew. 2017. Pengaruh Good Corporate Governance Terhadap Firm Performance Pada Seluruh Sektor Non-Keuangan BEI Periode 2013-2016 [Skripsi]. Surabaya: Universitas Surabaya.

Nyeadi et al. 2018. Corporate Social Responsibility and Financial Performance Nexus: Empirical Evidence From South African Listed Firm. Journal of Global Responsibility. DOI:10.1108/JGR-01-2018-0004

Prior et al. 2008. Are Socially Responsible Managers Really Ethical? Eksploring The Relationship between Earnings Management and Corporate Social Responsibility. Journal Compilation. 16(3).

Rodrigs et al. 2017. Impact of Board Structure on Firm Performance: Evidence from an Emerging Economy. Journal of Asia Business Studies. 11(2), 210-228. DOI:10.1108/JABS-06-2015-0067

Sabatini K, Sudana IP. 2019. Pengaruh Pengungkapan CSR terhadap Nilai Perusahaan dengan Manajerial Laba sebagai Variabel Moderasi. Asia-Pacific Jurnal Ilmiah Akuntansi dan Bisnis. 14(1), 56-69.

Sial et al. 2018. Corporate Social Responsibility, Firm Performance and The Moderating Effect of Earning Management in Chinese Firms. Asia-Pacific Journal of Business. DOI:10.1108/APJBA-03-2018-0051

Wijaya E, Sherly. 2017. Analyze the Effect of CSR on Corporate Financial Performance with Earning Management as Moderating Variable. Bilancia. 1(4), 2549-5704. 